\title{
Retraction Note: Bone mesenchymal stem cell-derivedexosomal microRNA-29b-3p preventshypoxic-ischemic injury in rat brain byactivating the PTEN-mediated Aktsignaling pathway
}

Kun Hou', Guichen $\mathrm{Li}^{2}$, Jinchuan Zhao', Baofeng $X \mathrm{u}^{1}$, Yang Zhang ${ }^{1}$, Jinlu Y $\mathrm{u}^{1 *}$ and Kan $\mathrm{Xu}{ }^{1 *}$

Retraction to: J Neuroinflammation 17, 46 (2020)

https://doi.org/10.1186/s12974-020-1725-8

The authors have retracted this article [1] because they have been unable to replicate the results of their study. After publication they expanded the sample size and repeated the measurements, and found that miR-29b-3p was not always down-regulated in the rat MCAO model and OGD cell model. In addition, when the processing time was doubled, miR-29b-3p showed an upward trend. The conclusions presented are therefore not reliable. All authors agree with this retraction.

\footnotetext{
Author details

'Department of Neurosurgery, The First Hospital of Jilin University, No. 1Xinmin Avenue, Changchun 130021, Jilin, People's Republic of China. ${ }^{2}$ Department of Neurology, The First Hospital of Jilin University, Changchun 130021, People's Republic of China.
}

Published online: 23 November 2020

\section{Reference}

1. Hou K, Li G, Zhao J, Xu B, Yang Z, Yu J, Kan X. Bone mesenchymal

stem cell-derived exosomal microRNA-29b-3p prevents hypoxic-ischemic injury in rat brain by activating the PTEN-mediated Akt signaling pathway. J Neuroinflammation. 2020;17:46 https://doi.org/10.1186/ s12974-020-1725-8.

The original article can be found online at https://doi.org/10.1186/s12974020-1725-8.

*Correspondence: jlyu@jlu.edu.cn; xu_xukan@126.com

'Department of Neurosurgery, The First Hospital of Jilin University, No. 1Xinmin Avenue, Changchun 130021, Jilin, People's Republic of China

Full list of author information is available at the end of the article

C C The Author(s). 2020 Open Access This article is licensed under a Creative Commons Attribution 4.0 International License, which permits use, sharing, adaptation, distribution and reproduction in any medium or format, as long as you give appropriate credit to the original author(s) and the source, provide a link to the Creative Commons licence, and indicate if changes were made. The images or other third party material in this article are included in the article's Creative Commons licence, unless indicated otherwise in a credit line to the material. If material is not included in the article's Creative Commons licence and your intended use is not permitted by statutory regulation or exceeds the permitted use, you will need to obtain permission directly from the copyright holder. To view a copy of this licence, visit http://creativecommons.org/licenses/by/4.0/ The Creative Commons Public Domain Dedication waiver (http://creativecommons.org/publicdomain/zero/1.0/) applies to the data made available in this article, unless otherwise stated in a credit line to the data. 